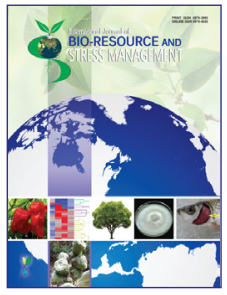

\title{
Causes and Control Measures of Apple Replant Problem
}

\author{
N. C. Sharma ${ }^{1 *}$, Pramod Verma ${ }^{1}$, Niranjan Singh ${ }^{1}$ and Babita ${ }^{2}$
}

${ }^{1}$ Dept. of Fruit Science, Dr. Y S Parmar University of Horticulture and Forestry, Nauni, Solan- Himachal Pradesh (173 230), India ${ }^{2}$ Horticulture Development Officer, Government of Himachal Pradesh, India

\section{Open Access Corresponding Author}

\section{N. C. Sharma e-mail: naveenuhf@gmail.com}

Citation: Sharma et al., 2020. Causes and Control Measures of Apple Replant Problem-A Review. International Journal of Bio-resource and Stress Management 2020, 11(3), 246-257. HTTPS://DOI ORG/10.23910/1.2020.2090.

Copyright: (c) 2020 Sharma et al. This is an open access article that permits unrestricted use, distribution and reproduction in any medium after the author(s) and source are credited.

Data Availability Statement: Legal restrictions are imposed on the public sharing of raw data. However, authors have full right to transfer or share the data in raw form upon request subject to either meeting the conditions of the original consents and the original research study. Further, access of data needs to meet whether the user complies with the ethical and legal obligations as data controllers to allow for secondary use of the data outside of the original study.

Conflict of interests: The authors have declared that no conflict of interest exists.

\begin{abstract}
Replant problem is a situation resulting in suppression of growth and poor productivity of the trees planted on old orchard sites and makes the plantations un-economical. It is a serious malady throughout the world in some fruit crops where the new plantations are done at the old orchard sites. Although replant problem is known to exist for many decades but greater attention was paid to this phenomenon only when Thompson (1959) while working at East Malling Research Station, United Kingdom observed poor growth of apple and cherry on old plantation sites. This observation strongly stimulated replant research in different parts of the world. Western Himalayan states of India are also facing the replant problem where majority of apple orchards have out lived their economic life and new plantations are being done at the same site. The incidence of apple replant disease on various sites has been observed 25-70 per cent. It is comparatively easy to prevent the replant problem than to control it because of unknown exact etiology and complex nature of malady due to the presence of different biotic and abiotic factors associated with the problem. Nature and intensity of the incidence is highly variable from country to country and even region to region and there is lack of quick diagnostic methods. The problem is difficult to control with one method and require integrated management practices for effective control.
\end{abstract}

Keywords: Apple, replant problem, causes, biotic stress, control measures

\section{Introduction}

Amongst fruit crops, apple is an important crop of temperate regions of the world. Its plants fail to survive or show poor growth when planted on a site where apple was grown earlier. This is a serious problem all over the word for the establishment of new apple orchards on old sites. The problem becomes more serious in the present context when there is a trend towards high-density plantations, using dwarf scion and stock combination. The economic life of such dwarf trees is very short and need to be replanted after a short span of 15-20 years. Apple replants problem is a complex problem that reduces survival, growth and yield of replanted trees and is often encountered in establishing new orchards on old sites (Yao et al., 2006). It is a common problem typified by stunted growth and reduced yields in successive plantings of apple on old orchard sites (Leinfelder and Merwin, 2006). The disease is a complex syndrome that affects young trees in replanted orchard sites causing necrotic lesions on feeder roots, stunted tree growth and reduced cumulative yields

\section{Article History}

RECEIVED in $11^{\text {th }}$ April 2020 RECEIVED in revised form $30^{\text {th }}$ May 2020 ACCEPTED in final form $02^{\text {nd }}$ June 2020 
(Rumberger et al., 2007). According to Laurent et al. (2008), apple replant problem is a soil-disease syndrome of complex etiology that affects apple tree roots in replanted orchards, resulting in stunted tree growth and reduced yields.

Buszard and Jensen (1986) reported the more conspicuous effect of the disease in soil samples from beneath trees than alleyways. The incidence is common all over the world and a plant growth reduction of 30-73 and 40-63 per cent has been observed in glasshouse pot trials and subsequent field trials, respectively along with 50 per cent reduction in average yield (Brown and Schimanski, 2002). However, the incidence of apple replant problem has been found 25-70 per cent in Himachal Pradesh (Bhardwaj and Sharma, 2004).

\section{Causes of the Problem}

The currently accepted concept of poor apple growth as a "specific replant disease" is considered unjustified and a possible barrier for the identification of the cause. The causal agents of apple replant problem must be either bacteria or actinomycetes, probably the latter as their temperature tolerance agreed with that of the disease (Otto, 1972). Experimental evidence indicated that the cause might be a common, widespread but variable soil malaise affecting many plants (Sewell, 1979). Pathogenicity of replant disease agents is considerably influenced by environmental conditions especially microbiological factors in the soils (Sewell et al., 1982). In apple orchards or nurseries, different biological agents have been implicated in disease development e.g. nematodes like Pratylenchus penetrans were found to attack the roots of every size and age but difficult to diagnose by above ground symptoms (Mai et al., 1994). The infected apple roots showed discoloured, stunted and sometimes 'witchesbroom' symptoms (Hoestra, 1994). Among the identified potential factors responsible for apple replant problem, most important are low soil $\mathrm{pH}$, poor irrigation practices and arsenic spray residues in the soil, soil compaction, nematodes and nutrient deficiencies (Willett et al., 1994). The aetiology of apple replant disease is biological in origin, complex and site-specific and involves a shift in soil microbial community composition towards pathogens dominating the soil microbial profile (Mazzola, 1999). The disease is attributed to biotic and abiotic factors and highly variable by sites, making it difficult to diagnose and overcome (Leinfelder and Merwin, 2006). The possible causes attributed to apple replant problem are as under:

\subsection{Fungi/actinomycetes}

Fungi or actinomycetes are considered as the major causal organisms responsible for apple replant problem. Pythium species may be involved in poor apple growth i.e. apple replant problem (Sewell, 1979). Several lines of circumstantial evidence collectively indicated that poor early growth of apple (replant disease) might be associated with the effects of soil-borne pythiaceous fungi (Sewell, 1981). Sewell et al.
(1982) related the apple replant problem to that of Pythium sylvaticum and reported that Pythium sylvaticum isolates inhibit root growth of apple and contain diffusible toxins. The association between the fungus and replant disease in soil contained a growth-suppressing factor of non-biological origin. Utkhede and Li (1989) collected nineteen fungal isolates from the soil of an orchard with apple replant problem and identified them as Mortierella sp., Torulomyces lagena and Trichoderma hamatum. Interactions between soil fungi such as Phytophthora species and Pratylenchus penetrans are involved in apple replant problem (Utkhede et al., 1992). Braun (1995) observed that replant disease-like symptoms in apple which were caused by Cylindrocarpon lucidum and Pythium species. According to Mazzola (1998) fungi viz., Phytophthora cactorum, Pythium species and Rhizoctonia solani are the dominant causal agents of apple replant problem. Isutsa and Merwin (2000) isolated various Pythium, Cylindrocarpon, Fusarium, Rhizoctonia and Phytophthora species from roots of apple plants grown in the replant test soil. While analyzing the etiology of apple replant problem, Rabie et al. (2001) reported a complex of fungal genera, i.e. Rhizoctonia, Cylindrocarpon, Pythium and Phytophthora as the dominant causal agents for the disease.

Apple replant problem is a soil-borne disease that may be caused by nematodes, bacteria and fungi viz., Rhizoctonia, Pythium and Phytophthora (Brown and Schimanski, 2002). However, Mazzola (2003) suggested Pratylenchus species as the causal organism of this disease. Molnar et al. (2003) detected Rosellinia necatrix in the roots of plants grown on apple replanting sites and reported it as the causal organism of the disease. Fungi and oomycetes belonging to the wellknown root rot complex, Rhizoctonia solani, Phytophthora species., Cylindrocarpon species and Pythium species were also shown to be an important factor of replant disease (Manici et al., 2003; Manici and Caputo, 2010; Kelderer et al., 2012). Otto and Winkler (1977) detected actinomycetes in the damaged feeder roots and microscopically visible injury of apple trees and considered actinomycetes as a causal organism of this disease. Westcott et al. (1986) established an association between infectious actinomycetes and apple replant problem and reported that actinomycetes may be important in the aetiology of the disease. Westcott et al. (1987) found high levels of infection of the Actinomycete-like organisms in soil conducive to apple replant problem. Catska and Taube (1994) found phytotoxic micromycetes to cause apple replant problem.

Jensen and Buszar (1988) identified the involvement of Oomycetes in apple replant problem. Root pathogenic actinomycetes are the primary cause of specific apple replant problem (Otto and Winkler, 1993; Winkler and Szabo, 1995; Szabo et al., 1998). Otto et al. (1994) from their studies concluded that root exudates, as determined by the metabolism of growing terminal buds contain signal substances, which switch on the activities of root-pathogenic 
actinomycetes and lead to root infection. Otto and Winkler (1998) confirmed infection of woody plants of the family Rosaceae in soil with specific replant disease by actinomycetes resulting in damage of the cortical cells and finally in the death of the rootlets. Light microscopic investigation of rootlets of young apple seedlings grown in soil suffered from apple replants problem revealed the colonization of actinomycetes in cortical cells (Szabo et al., 1998). Various researchers have reported Rhizoctonia, Phytophthora, Pythium (Caruso et al., 1989), Alternaria, Cylindrocarpon, Fusarium, Rhizoctonia and Verticillium (Kowalik, 1999), Dematophora necatrix, Fusarium oxysporum, Phytophthora spp. and Pythium spp. (Kumar et al., 1998) to cause apple replant problem.

\subsection{Bacteria}

Fluorescent pseudomonas may act as growth inhibitors in apple seedlings and possibly a causative factor in the development of replant disease (Bunt and Mulder, 1973). Catska et al. (1982) found Pseudomonas putida as a cause of apple replant problem in Czechoslovakia. Two strains of Bacillus subtilis have been reported to be associated with stunting growth of apple seedlings in British Columbia by Utkhede and $\mathrm{Li}$ (1988). Waechter (1988) isolated bacteria from the soils of apple orchards with different levels of replant disease and reported it as a causal organism of the disease. Bacteria alone or in combinations with fungi and nematodes may contribute towards the occurrence of apple replant problem (Utkhede et al., 1992). However, contrary to this, Rumberger et al. (2007) reported that potentially antagonistic neither Pseudomonas nor rhizosphere cyanide concentrations appeared to be involved in the apple replant problem complex.

\subsection{Nematodes}

Winkler and Otto (1972) indicated that nematodes are not the main factor responsible for apple replant problem. Similarly, Mazzola (1998) found minor or no role of plant-parasitic nematodes in development of apple replant problem. Contrary to this, Szczygiel and Zepp (1998) reported that root parasitic nematodes (Pratylenchus penetrans) are responsible for the unspecific type of replant disease. Two agents, nematode and unknown organism present in field soil contribute to apple replant problem by inducing stunting and root discolouration symptoms (Jaffee et al., 1982). Isutsa and Merwin (2000) isolated phytophagous nematodes from roots of apple plants grown in the replant test soil.

\subsection{Fungus and nematode interaction}

Utkhede et al. (1992) suggested that interactions between soil fungi such as Phytophthora species and Pratylenchus penetrans are involved in apple replant problem. Histopathological studies have shown the presence of nematodes and hyphae of Rhizoctonia, Phytophthora and Pythium in the roots of apple trees in replant soil (Caruso et al., 1989). According to Mazzola et al. (2009) Pythium species and Pratylenchus penetrans were predominant components of the apple replant problem.

\subsection{Phytotoxins}

There are various evidences that the allelopathy has a drastic effect over the seedling and plant growth. The allelochemicals impair the physiological function of the cell directly or indirectly thus retard the plant growth and cause soil sickness in apple (Ajsaadawi and Rubeaa, 1985).

\subsection{Role of variety}

Different apple varieties respond differently in replant soil and show varying degree of replant disease. It is due to the growth and vigour pattern of the scion/stock, the root system of the stock and water and nutrient absorption capacity of the plant. O'Kennedy and Kavanagh (1980) found more severe effects of replant disease on Golden Delicious than Cox on M.9 rootstock. Northern Spy seedlings showed severe stunting and root discolouration symptoms when grown in untreated field soil obtained from an orchard with a history of apple replant disease (Jaffee et al., 1982).

\subsection{Orchard soil properties}

Poor growth of young apple trees on replant sites has been thought to be due to arsenic toxicity (Covey et al., 1979). Benson et al. (1978) established a negative correlation of seedling growth with soil arsenic concentration and reported that zero growth occurs at about $450 \mathrm{ppm}$ total arsenic concentration. According to Willett et al. (1994) and Potter (1999), low soil pH, poor irrigation practices, arsenic spray residues, soil compaction, nutrient deficiencies and selection of an inappropriate orchard system contribute to low soil fertility and the apple replant problem.

Low soil pH prevents the specific apple replant disorder (Jonkers and Hoestra, 1978). Contrary to this, Buszard and Jensen (1986) failed to establish any correlation between soil $\mathrm{pH}$ and apple replant problem. Apple replant problem appears to be more frequent in light sandy soil than heavy soils, however, growth improvement with control measures was reported to be better in light rather than heavy soils. The disease has been reported more frequent in neutral or slightly acidic soils than in more strongly acid soils. Szczygiel and Zepp (1998) observed more frequent occurrence of apple replant problem in light and neutral or slightly acidic soils than in heavy and acidic soils.

Deficiency of N, P and K in the soil cause physiological stresses that lead to replant problem (Merwin and Stiles, 1989). Li and Utkhede (1991) established positive relationships of major nutrient elements ( N, P and K) with plant height in apple replant soils. Moyls et al. (1994) found phosphorus deficiency as a nutritional factor associated with apple replant problem. Toxicity caused by the excess of $\mathrm{Mn}$ and Al (Hoyt and Neilsen, 1985) and heavy metals such as arsenic derived from pesticides (Benson, 1976) have also been implicated in replant problem of apple.

\subsection{Role of plant growth regulators}

Growth regulators, 1-naphthylacetic acid (NAA) and 
benzylaminopurine (BAP) spray promoted root infection very strongly in replant soils, whereas, gibberellins reduced infection at the lower level of apple replant disease (Otto et al., 1994).

\section{Control Measures}

Soil fumigation, increased recognition of soil physical/chemical/ moisture problems, reduced reliance on seedling rootstocks and an increase in the use of dwarfing as well as precocious rootstocks could be a management tool for better apple tree growth and production at old apple orchard soils (Willett et al., 1994). The disease may be controlled by the application of broad-spectrum fumigants, but environmental concerns necessitate the investigation of the organic alternative. Since the disease develops mainly through changes in soil microbial populations, the integration of biological soil amendments into production systems may shift the population balance towards a more beneficial microbial community (Barea et al., 2005; Cohen et al., 2005; Yao et al., 2006). Due to the adverse effects of disease on root proliferation and development, stimulation of root growth can also play an important role in managing it. Various control measures which have been found effective are discussed below:

\subsection{Chemical control}

Fumigation greatly increased the growth of apple trees at replanting site (Jackson, 1973). In most soils fumigation resulted in better tree growth than in untreated soil (Ross and Crowe, 1973). The growth of apple tree can be significantly improved by effective control of replant disease with chloropicrin (Ryan, 1975). Sewell and White (1979) obtained the effective control of apple replant problem using preplanting soil treatments with chloropicrin, propylene oxide, steam or formalin. Application of formalin @ $150 \mathrm{ml} / \mathrm{m}^{2}$ soil provides an economical and less hazardous alternative to chloropicrin for the control of apple replant problem (Sewell, 1979). Oehl (1980) reported that pre-planting fumigation of replant soil with chloropicrin @ 281 I ha-1 resulted in increased shoot numbers, trunk girth and total yield. Control of replant disease has typically relied on pre-plant application of broadspectrum soil fumigants (Mazzola and Gu, 2000). Brown and Schimanski (2002) recommended the use of Basamid (dazomet) for soil fumigation to control the disease.

Williams (1984) recorded significantly higher girth increment, total extension growth and fruit yield in trees planted into replant soil that was treated with chloropicrin (injections @ $28 \mathrm{ml} / \mathrm{m}^{2}$ ) and mulched with black polyethene film after planting. Slykhuis and Li (1985) effectively treated the soil infested with apple replant disease using methyl bromide (0.5 $\left.\mathrm{g}_{\text {litre }}^{-1}\right)$, captan (1 $\left.\mathrm{g} \mathrm{litre}^{-1}\right)$, chloropicrin $\left(0.2 \mathrm{~g} \mathrm{litre}^{-1}\right)$, formalin ( $\left.2 \mathrm{ml}^{\text {litre }} \mathrm{l}^{-1}\right)$, dazomet $\left(0.25 \mathrm{~g} \mathrm{litre}^{-1}\right)$, mancozeb $(0.5 \mathrm{~g}$ litre $\left.^{-1}\right)$, efosite-al $\left(0.1 \mathrm{~g} \mathrm{litre}^{-1}\right)$ and urea formaldehyde solution containing $10 \% \mathrm{~N}$ (1 ml litre $\left.{ }^{-1}\right)$. Methyl bromide has been the fumigant used most widely to control apple replant problem
(Szczygiel and Zepp, 1998). Gur et al. (1991) applied preplanting soil fumigation with methyl bromide, chloropicrin, 1 , 3-dichloropropene, 1, 2-dichloropropane and Vorlex (methyl isothiocyanate + 1, 3-dichloropropene, 1, 2-dichloropropane) either singly or in combinations in replanting apple sites and found that fumigation with a small amount of methyl bromide was much less effective than double fumigation, first with chloropicrin and then with methyl bromide.

Ross et al. (1983) reported that fumigation with vortex (methyl isothiocyanate) significantly increased the trunk cross-sections of apple trees in replant sites. Covey et al. (1984) recommended the use of formaldehyde (0.06-0.43 $\mathrm{mg} \mathrm{kg}^{-1}$ soils) instead of chloropicrin or methyl bromide for effectively alleviating growth suppression indicative of an apple replant problem. Jensen and Buszard (1988) found post-planting applications of metalaxyl @ 0.312/0.600 mg a.i./litre at weekly or biweekly intervals as effective as steam sterilization for controlling apple replant disease. Application of the fungicides difenoconazole or metalaxyl enhanced the growth of apple plants in replant soils (Mazzola, 1998). Bavistin (0.2\%), Jkstein (0.2\%) and Dithane Z-78 also found to improve growth of apple plants in replant soils but not as effective as formalin. Line et al. (2003) compared the efficacy of Telone C35 (chloropicrin), Basamid (dazomet) and the standard methyl bromide at apple replant sites and reported significantly greater control of replant problem with methyl bromide and Telone C 35 than the untreated control and the Basamid treatments.

\subsection{Cultural control}

Costante (1990) had outlined a programme of cultural practices to reduce losses due to diseases at apple replanting sites. Since, apple replant problem has been recognized as a soil borne problem, the attention is needed towards modification of cultural practices such as to dig the pit slightly away from the old one, take out old roots before replanting, destroy them, removal of hardpan at sub-soil level and avoid water logging. Different cultural practices reported to control apple replant problem are as under:

\subsubsection{Application of soil amendments and fertilizers}

The organic amendments have a variety of beneficial properties in addition to their ability to supply nutrients and improve soil water holding capacity. The disease-suppressive effects of compost have been established (De Ceuster and Hoitink, 1999; Noble and Coventry, 2005) and mechanisms of disease suppression have been attributed mainly to the microbial activities inherent to them (Ristaino and Thomas, 1997). Compost or earthworm humus added to the soil placed in planting holes of replanted apples considerably increased growth rates (Gur et al., 1998). Organic substances may not only influence soil structure and its moisture but can also modify the composition of microflora in a direction beneficial to young roots (Szczygiel and Zepp, 1998). The general biological activity of the soil is stimulated by addition of an 
available carbon source (Campbell, 1989; Magarey, 1999) and soils with a diversity of beneficial microorganisms are more likely to be suppressive to disease development (Lazarovits, 2001). Mazzola et al. (2001) suggested the use of Brassica napus seed meal amendments for the management of apple replant disease (Rhizoctonia species) as this amendment controlled the disease by mechanisms other than the production of glucosinolate hydrolysis products. Wilson et al. (2004) had grown apple plants for 4 weeks in a soil-less potting mix before transplanting into replant soil pasteurized or amended with various levels of organic matter and found to produce markedly longer extension growth than trees planted directly into replanting soil. While comparing fumigation and compost treatment for control of apple replant problem, Yao et al. (2006) recorded longer lateral extension growth in trees growing in compost-treated soil as compared to those under fumigation treatment. Mazzola et al. (2007) suggested the use of a composite Brassica juncea and Brassica napus seed meal mixture for effective control of the pathogen complex inciting apple replant disease relative to either seed meal used alone. Applications of compost and compost extracts were identified as promising practical tools for managing replant disease. In pot trials, the application of compost and sterilized as well as unsterilized compost extracts to apple replanting soil was found to significantly increase the growth of apple seedlings (Schoor et al., 2009).

Hudska et al. (1987) recorded 2.17 fold higher growth with liquid fertilizer and 1.76 fold higher growth with potassium sulphate at replant sites and suggested soil acidification and sulphuric acid treatment of old orchard soils for control of replant disease. Fertilization with mono ammonium phosphate corrected stunting effect and effectively promoted the growth of apple plants at replanting sites (Utkhede and Li, 1989; Utkhede and Smith, 1993). Utkhede and Smith (1991a) recorded a significant increase in seedling height with the application of $\mathrm{N}$ and $\mathrm{P}$ fertilizers in soil infested with fungi and bacteria causing replant disease. They further reported that $\mathrm{N}$ and $\mathrm{P}$ promoted the growth of bacteria antagonistic organisms associated with replant disease. Mono ammonium phosphate was found more effective than Bacillus subtilis and formalin in increasing total shoot length and trunk cross-sectional area of 2-year-old McIntosh plant on M.26 rootstock (Utkhede and Smith, 1994). Szczygiel and Zepp (1998) recommended the use of bio-humus amendment at 10-20 per cent and mono ammonium phosphate at $2 \mathrm{~g}$ litre $^{-1}$ of soil for effective control of apple replant problem. Wilson et al. (2004) examined the response of young apple trees to amendment of apple replant problem soils using mono ammonium phosphate, organic matter or replacement soil and reported that mono-ammonium phosphate at 1 and 2 $\mathrm{g}^{-1}$ of soil resulted in a significant improvement in first year radial growth, but higher rates of mono-ammonium phosphate were found toxic. Wojcik and Klamkowski (2008) mixed the mono ammonium phosphate with soil @ of 1,2 and $3 \mathrm{~g} \mathrm{l}^{-1}$ before planting and recommended the application of monoammonium phosphate @ of $1 \mathrm{~g} \mathrm{l}^{-1}$ for coarse-textured soils with low $P$ status in the soil solution to increase precocity of apple trees. In replanting, soils absence of mycorrhiza leads to the unavailability of phosphorus due to soil absorptive complex. In such situations, mono ammonium phosphate application reduces the negative effect of replant disease and enables young roots to use phosphorus without mycorrhiza.

Use of plastic mulch against apple replant problem was as effective as fumigation with methyl bromide, chloropicrin or formalin (Jensen and Buszard, 1988). Engel et al. (1994) recommended the planting of two-year-old nursery plants than one-year-old plants in replant disease affected soils for higher growth and vigour. Application of peat and drip irrigation enhanced shoot growth in replant soils (Dencker and Hansen, 1995). Szczygiel and Zepp (1998) suggested that activated charcoal controls replant disease to some extent. The ethylene content in the soil and root environment of replanted apple plants was reduced by adding activated charcoal to the soil or by soil fumigation with methyl bromide (Gur et al., 1998). Leinfelder and Merwin, (2006) studied the effect of planting position on tree growth and reported that trees planted in old grass lanes perform better than those in the old tree rows. According to Rumberger et al. (2007), avoiding replanting into the old tree rows coupled with the use of tolerant rootstocks appeared to be the best strategy for reducing apple replant problem. Addition of slow-release fertilizers, compost and mulch extracts significantly increased the growth parameters and survival of apple seedlings in replant soil (Engel et al., 2001; Schoor et al., 2009).

\subsubsection{Intercropping}

Antagonistic activity of marigold and grasses like red fescue and red top has been recorded against Pratylenchus penetrans by Townshend et al. (1984). Intercropping with herbaceous crops greatly improves the apple seedling growth in replanting soils (Vrain and Yorston, 1987). Crops like mustard, radish, cabbage etc are effective in controlling the soil borne pathogens. These crops release volatile gases, which are effective against the soil borne pathogens (Gamliel and Stapleton, 1993). Edwards et al. (1994) conducted field trials to test the effectiveness of antagonistic plants on the populations of Pratylenchus penetrans and Pythium species in replant soils and found that marigold (Tagetes patula, cv. Harmony), creeping red fescue (Festuca rubra) as well as red top (Agrostis alba) substantially decreased the population of Pratylenchus penetrans and Pythium species, whereas, canola crop substantially increased the population of these pathogens.

In greenhouse studies, cultivation of wheat in replant orchard soils prior to planting suppressed disease development. Under controlled conditions, cultivating replant soils with wheat prior to planting apple resulted in reduced root infestation by Pythium species, Rhizoctonia species and Pratylenchus 
penetrans and enhanced seedling growth (Mazzola and Gu, 2000). The microbial community resident in a wheat field soil was shown to suppress components of the microbial complex that incites apple replant problem (Mazzola et al., 2002). Wheat cultivation prior to planting, modified the genetic and species composition of the fluorescent pseudomonas population resident to orchard soil and substantially enhanced apple seedling growth (Gu and Mazzola, 2003). Contrary to this, Mazzola, (2003) observed no significant impact of cultivation of replant orchard soils with a perennial/annual ryegrass mixture prior to planting of Gala seedlings. Mazzola and Mullinix (2005) evaluated the influence of cultural practices including cover crops and incorporation of Brassica napus seed meal on the control of apple replant problem and reported that napus seed meal significantly enhanced vegetative growth and yield of Gala/M.26 compared to methyl bromide soil fumigation. Contradictory to this, Mazzola and Mullinix, (2005) observed that Brassica napus green manure neither suppressed disease development nor enhanced tree growth. Mazzola et al. (2006) advocated the Brassica napus seed meal induced control of Rhizoctonia solani because it enhanced the activity of resident soil microorganisms, specifically Streptomyces species.

\subsubsection{Use of resistant/tolerant rootstocks}

Rootstock selection and row repositioning have been found to be more beneficial than soil fumigation or compost amendments in controlling apple replant problem. Development of replanting resistant rootstocks for apple is a slow and lengthy process and sometimes the resistance obtained is lost by the time plant comes into a productive stage. In replant apple soils, Ryan (1975) suggested the use of M.12 rootstock for sites susceptible for root diseases, MM.115 and M.793 for lighter soils and M.793 for heavier soils with chloropicrin fumigation. Costante et al. (1985) reported that apple rootstock MM.111 roots in clay had fewer Pratylenchus penetrans than MM.106 roots. Rootstock genotypes modified their rhizosphere environments which differed significantly in their bacterial, Pseudomonas, fungal and oomycetes communities. Although none of the apple accessions has found completely resistant to replant disease in the test soil, however, seedling accessions of Malus sieversii and Malus kirghisorum had some tolerance and three clonal rootstock accessions viz., CG.65, CG.6210 and CG.30 and four other clones like Malus baccata 1883, Malus xanthocarpa Xan, Malus spectabilis PI 589404 and Malus mandshurica 364 had good tolerance (Isutsa and Merwin, 2000). Rootstock genotype had the dominant influence on root lifespan and distribution, whereas pre-plant soil fumigation, compost amendments and replanting positions had a little apparent impact on root characteristics despite their influence on above-ground tree growth and yield (Yao et al., 2006). Leinfelder and Merwin (2006) recorded better growth and higher yield of apple on CG.6210 and CG.30 clonal rootstocks than those on other rootstocks and reported that clonal rootstocks were more beneficial than soil fumigation or compost amendments in controlling apple replant problem. Yao et al. (2006) evaluated the response of five clonal rootstock genotypes (M.7, M.26, CG.6210, G.30 and G.16), in an apple replant site and recorded highest growth and yield on CG.6210 rootstock, while trees on M.26 rootstocks had the least growth and lowest yield. They categorized the rootstocks M.7, M.26 and CG.16 as susceptible, while CG.30 and CG.6210 as tolerant to apple replant problem. Use of apple replant problem tolerant rootstocks is an emerging control strategy (Rumberger et al., 2007). Out of seven rootstocks studied, Angelika et al. (2010) found CG.30 and CG.6210 clonal rootstocks relatively tolerant to the apple replant problem on the basis of rootzone soil microbial consortia and the relative severity of apple replant problem. The genotype-specific interactions with soil microbial consortia were linked with apple rootstock tolerance or susceptibility to replant problem by Laurent et al. (2010). Auvil et al. (2011) from their studies on 65 rootstocks and three scion cultivars (Gala, Fuji and Honeycrisp) in modern, high-density systems at replant sites concluded that trees on $\mathrm{G} .41$ and $\mathrm{G} .11$ rootstocks had less vigour than trees on G.935, CG.4214, G.202, and CG.4814. Wang et al. (2011) evaluated adaptability of five rootstocks viz., Malus sieversii, M. micromalus, M. hupehensis, $M$. baccata and $M$. micromalus to replant soils with pot trials and concluded that $M$. hupehensis had a better tolerance to replant problem and plants on this rootstock exhibited the lowest decrease in photosynthesis rate, chlorophyll and carotenoids contents. Various research workers have reported the susceptibility of MM.106, MM.111 (Mazzola, 2003), M.26 (Mazzola, 2003; Rumberger et al., 2004; Laurent et al., 2010), M.7, CG.16 (Rumberger et al., 2004) and G.65 (Laurent et al., 2010) to the disease. However, G.30, CG.210 (Isutsa and Merwin, 2000; Rumberger et al., 2004; Laurent et al., 2010), CG.5935, CG.4202 (Robinson et al., 2004) and M.793 (Soni et al., 2011; Singh and Sharma, 2017; Singh at al., 2017; Singh et al., 2018) have been reported as tolerant rootstocks to apple replant problem.

\subsubsection{Use of mulches}

Soil solarization with polyethene mulch alone or in combination with soil fumigation with certain fumigants like formaldehyde is effective against the soil-borne pathogens. In controlling replant disease, plastic mulches as a cultural treatment have been found as effective as methyl bromide, chloropicrin and formalin (Jensen and Buszard, 1988). Cultural practices of deep ploughing and use of grass mulch between the rows have been found effective against apple replant problem by Engel (1988).

\subsection{Biological control}

Although soil fumigation and chemicals are most adaptive mean to control replant problem but not attractive as they disturb natural equilibrium between pathogen and antagonistic microorganisms in the soil. Utkhede and Smith 
(1991b) recorded an increase in tree growth of apple in the replanting site by soil drenching with Bacillus subtilis. Agrobacterium radiobacter improves the growth of apple plants grown in soil with the apple replant problem (Catska and Taube, 1994).

Parasitism of pathogenic fungi by other fungi is generally termed as "Mycoparasitism". Some of these mycoparasites, such as Trichoderma spp., have a very broad host range while others, such as chytrids are host specific. When a mycoparasite is grown with its host in dual culture, hyphae may coil around the host and hook-like structure (appressoria) are formed. The recognition phenomena involving agglutinin (lectin) from the host binds to carbohydrate residues on the cell walls of Trichoderma spp. was supported by fluorescent indicators and enzyme studies which provided evidence for enzymatic activity leading to penetration of host hyphal cell by mycoparasites. Mycoparasites produce hydrolytic enzymes; $\beta-1$, 3 glucanases, cellulase and chitinase in appropriate to the cell wall substrate. Involvement of numerous separate genes and gene products has been reported in mycoparasitic interactions by Harman et al. (1989) and suggested the involvement of chitinase and $\beta-1,3$ glucanases in Trichoderma mediated bio-control.

Bacterial strain EBW-4 of Bacillus subtilis and Strain B8 of Enterobacter aerogenes were found to have potential for field control of apple replant problem in orchards. Application of BACT-1 and EBW-4 under field conditions leads to increase shoot growth in unfertilized and unpasteurized apple replanted soils (Utkhede and Li, 1989). The post planting drench application of strain EBW-4 of Bacillus subtilis alone or in combination with formalin fumigation effectively increased trunk cross-sectional area, shoot growth and fruit yield of apple, which showed the potential of this bacterium for biological control of replant disease (Utkhede and Smith, 1992). Mycorrhizal fungus Glomus mosseae used alone or in combination with Enterobacter aerogenes and peat significantly increased their growth in replanted apple soil and effectively control the replant problem (Utkhede et al., 1992). Two mycorrhizal fungi, Glomus species D13 and Glomus intraradices increased total shoot length and the number of shoots per rootstock in apple replant soils (Taube and Baltruschat, 1993). Utkhede and Smith (2000) recorded increase in growth and fruit production of apple in soil conducive to replant disease with the application of biological agents (strain B8 of Enterobacter agglomerans, strain EBW-4 of Bacillus subtilis and Glomus intraradices).

A radiobacter may affect the plants by changing the composition of the rhizosphere microflora and by reducing the number of colony-forming units of phytotoxic micromycetes contributing to replant disease (Catska and Hudska, 1993). Inoculation of apple seedlings and rootstocks with Agrobacterium radiobacter improved the growth of apple plants grown in soil with replant problem (Catska and Taube, 1994). Similarly, inoculation with the vesicular-arbuscular mycorrhizal fungus Glomus etunicatum successfully controls the apple replant problem. Apple replant problem was suppressed by inoculation of apple-tree seedlings with Glomus fasciculatum and Glomus macrocarpum (Catska, 1994), which showed that the use of some VAM fungi could replace chemical treatments of soil against apple replant problem. The strain EBW4 of Bacillus subtilis has potential for biological control of the apple replant problem (Utkhede and Smith, 1994). The application of Enterobacter agglomerans (B8), Bacillus subtilis (EBW-4), Glomus intraradices (GI), significantly increased fruit yield and tree trunk growth and reduced infection by Phytophthora cactorum and Pythium ultimum in the soil conducive to replant disease (Utkhede and Smith, 2000). Rabie et al. (2001) suggested the use of biological formulations and soil composts for the control of the replant problem. Bharat and Bhardwaj (2001) studied the interaction between five species of VAM and Dematophora necatrix and found that local isolate of Glomus species was most effective in reducing disease severity, increasing VAM root colonization and increasing different plant growth parameters of six-month-old apple seedlings. Arbuscular mycorrhizae colonisation of apple roots at planting in different replant problem soils resulted in increased arbuscular mycorrhizae population in chloropicrin fumigated or fungicide treated pot soils (Kandula et al., 2006). Development of fungal and pseudomonas communities in the rhizosphere of the different rootstock genotypes may be important factor influencing tree growth and yield at apple replant sites (Yao et al., 2006). Raj and Sharma, (2009) tested four isolates of VAM and two isolates of Azatobacter chrococcum on seeds and seedlings of Golden Delicious against Dematophora necatrix (root rot of apple) and found that AZUHF1 isolates of $A$. chrococcum and AMUHF1 (Glomus fesiculatum) were the best treatments in increasing the shoot and root length.

\subsection{Thermal control}

Soil steaming at $60{ }^{\circ} \mathrm{C}$ or above for $45-60$ minutes is required to remove growth-inhibiting agents from replant apple orchard sites (Winkler and Otto, 1972). Soil steaming temperatures up to 50 ㅇ $\mathrm{C}$ did not alter the growth suppression induced by replant disease, whereas, $60{ }^{\circ} \mathrm{C}$ steaming improved subsequent shoot growth and $70 \circ \mathrm{C}$ permitted normal growth of plants (Otto, 1972). According to Moyls et al. (1994), steam heat treatments of soil reduced the effects of apple replant disease and steam for 1 minute showed 68 per cent better growth, while steaming for 2 minutes showed 120 per cent growth improvement. Mazzola (1998) reported that soil pasteurization enhanced the growth of apple plants and resulted in the change in the composition of the fungal community.

\subsection{Integrated management}

The exact cause of the replant problem is difficult to investigate as it can vary from region to region. Therefore, it is difficult to control the problem with only one method of management 
hence, integrated management could be an effective tool for the management of replant problem. Baxter (1977) reported that soil treatment with Vertafume and mulching with sawdust or plastic, markedly increased tree growth (total shoot length and trunk cross-sectional area) at replanting sites. Utkhede and Li, (1989) suggested the use of bacterial strain B8 in combination with mono-ammonium phosphate and lime in combination with fumigation and bacterial strains (EBW-4 of $B$. subtilis and strain B8 of Enterobacter aerogenes) for effective control of the disease. Utkhede and Smith, (1993) reported that although the application of mono-ammonium phosphate alone may be sufficient to alleviate the replant problem but the addition of Bacillus subtilis strains BACT-1 or EBW-4, or Enterobacter aerogenes strain B-8 to this treatment may be beneficial to increase tree growth. Granatstein and Mazzola (2001) advocated the integration of cultural and biological methods for control of apple replant problem. Use of topsoil + additional $P+$ formalin drench was found the most effective control of apple replant problem by Bhardwaj and Sharma, (2004) in Kullu valley of Himachal Pradesh. Soil fumigants helped in controlling apple replant problem when applied in combination with biological and cultural practices (Angelika et al., 2004). Wheat cropping controlled apple replant problem and enhanced fruit yield, whereas, Brassica napus seed meal amendment in concert with a post-plant mefenoxam soil drench was found as the sole treatment to provide a growth and yield response equivalent to soil fumigation (Mazzola et al., 2006). Avoiding replanting into the old tree rows coupled with the use of tolerant rootstocks appeared to be the best strategies for reducing replant problem in apple orchards (Rumberger et al., 2007). Kandula et al. (2010) reported improvement in growth of apple in replant site with commercial Trichoderma formulations and nitrogen, phosphorus as well as potassium (NPK) supplements.

\section{Conclusion}

Apple replant problem is a serious problem in the establishment of new orchards at old sites. The disease is a complex syndrome, caused by various biotic and abiotic agents and results in poor survival, growth and yield of young replanted apple trees. The soil fumigation and solarization have been found more effective in its control, but due to complex nature of the problem, integrated management practices combining chemical, cultural and biological methods should be given preference as control measures. The detailed research on quick and correct diagnosis of biotic and abiotic causes of the problem and management through eco-friendly techniques is the need of the present time.

\section{References}

Ajsaadawi, I.S., Rubeaa, A.J., 1985. Allelopathic effects of Citrus aurantium L. vegetational patterning. Journal of Chemical Ecology 11, 1515-1525.

Angelika, R., Shengrui, Y., Ian, AM., Nelson, EB., Thies, JE.,
2004. Rootstock genotype and orchard replant position rather than soil fumigation or compost amendment determine tree growth and rhizosphere bacterial community composition in an apple replant soil. Plant and Soil 264, 247-260.

Angelika, S., Laurent, IA., Merwin, GF., Thies, JE. and Michael, G., 2010. Brown rootstock genotype succession influences apple replant problem and root-zone microbial community composition in an orchard soil. Plant and Soil 337, 259-272.

Auvil, TD., Schmidt, T.R., Hanrahan, I., Castillo, F., McFerson, JR. and Fazio, G., 2011. Evaluation of dwarfing rootstocks in Washington apple replant sites. Acta Horticulturae 903, 265-271.

Barea, J.M., Pozo, M.J., Azcon, R., Azcón-Aguilar, C., 2005. Microbial co-operation in the rhizosphere. Journal of Experimental Botany 56, 1761-1778.

Baxter, P., 1977. Effect of soil fumigation and soil management on replant apple trees. Australian Journal of Experimental Agriculture and Animal Husbandry 11, 105-112.

Benson, N.R., 1976. Retardation of apple tree growth by soil arsenic residue. Journal of the American Society for Horticultural Science 101, 251-253.

Benson, N.R., Covey, RP. Jr., Haglund, WA., 1978. The apple replant problem in Washington State. Journal of the American Society for Horticultural Science 103, 156-158.

Bharat, N.K., Bhardwaj, LN., 2001. Interactions between VAmycorrhizal fungi and Dematophora necatrix and their effect on health of apple seedlings. Indian Journal of Plant Pathology 19, 47-51.

Bhardwaj, S.S., Sharma, I.M., 2004. Replant problem in applecauses and management. In: Productivity of temperate fruits, Jindal, KK., Gautam, D.R., (eds), Dr. Y. S. Parmar University of Horticulture and Forestry, Solan, H.P., India 417-422.

Braun, P.G., 1995. Effects of Cylindrocarpon and Pythium species on apple seedlings and potential role in apple replant problem. Canadian Journal of Plant Pathology 17, 336-341.

Brown, G., Schimanski, L., 2002. New weapon to combat apple replant problem. Pome Fruit Australia 10-12.

Bunt, J.A., Mulder, D., 1973. The possible role of bacteria in relation to the apple replant problem. Meded Fac Landbouwwet Rijksuniv Gent 38, 1381-1385.

Buszard, D.J., Jensen, P., 1986. A note on the incidence of apple replant problem in Quebec Canada orchards. Phytoprotection 67, 133-136.

Campbell, R., 1989. Biological control of microbial plant pathogens. Cambridge University Press, Cambridge 112-160.

Caruso, F.L., Neubauer, B.F., Begin, M.C., 1989. A histopathological study of apple roots affected by replant disease. Canadian Journal of Botany 67, 742-749.

Catska, V., 1994. Interrelationship between vesicular- 
arbuscular mycorrhiza and rhizosphere microflora in apple replant problem. Biologia Plantarum 36, 99-104.

Catska, V., Hudska, G., 1993. Use of Agrobacterhmi radiobacter for biological control of apple replant problem. Acta Horticulturae 324, 67-72.

Catska, V., Taube, B.H., 1994. Biological control of replant problems. Acta Horticulturae 363, 115-120.

Catska, V., Vancura, V., Hudska, G., Prikryl, Z., 1982. Rhizosphere microorganisms in relation to the apple replant problem. Plant and Soil 69, 187-197.

Cohen, M.F., Yamasaki, H., Mazzola, M., 2005. Brasssica napus seed meal soil amendment modifies microbial community structure, nitric oxide production and incidence of Rhizoctonia root rot. Soil Biology and Biochemistry 37, 1215-1227.

Costante, J.F., 1990. Apple replant problem; what is it, and how do you combat it? Proceedings of the Annual Meeting, Massachusetts Fruit Growers' Association 96, 81-86.

Costante, J.F., Mai, W.F., Klein, R.M., 1985. Effects of rootstock and soil type on Pratylenchus penetrans populations in apple feeder roots. Journal of the American Society for Horticultural Science 110(1), 38-41.

Covey, R.P., Koch, B.L., Larsen, H.J., Haglund, W.A., 1984. Control of replant disease with formaldehyde in Washington. Plant Disease 68, 981-983.

Covey, R.P., Benson, N.R., Haglund, W.A., 1979. Effect of soil fumigation on the apple replant problem in Washington. Phytopathology 69, 684-686.

De Ceuster, T.J.J., Hoitink, H.A.J., 1999. Prospects for composts and biocontrol agents as substitutes for methyl bromide in biological control of plant diseases. Compost Science \& Utilization 7, 6-15.

Dencker, I., Hansen, P., 1995. Effects of plant and soil factors on growth of young apple and blackcurrant plants. Acta Agriculturae Scandanavica; Section B. Soil and Plant Science 45, 73-77.

Edwards, L., Vrain, T., Utkhede, R.S., 1994. Effect of antagonistic plants on apple replant problem. Acta Horticulturae 363, 135-140.

Engel, A., Kunz, A., Blanke, M., 2001. Effects of compost and wood chippings on soil nutrients and on vegetative and reproductive growth and fruit quality of apple to overcome the replant problem. Erwerbsobstbau 43(6), 153-160.

Engel, G., 1988. Result of trials on apple replant problem at Klein-Altendor Experimental Station. Acta Horticulturae 233, 95-102.

Engel, G., Schmitz, H.E., Heinrichs, P. and Soimtag, J., 1994. Comparison of pruning methods in a replanted apple orchard. Enverbsobstbau 36, 88-92.

Gamliel, A., Stapleton, J.J., 1993. Characterization of different antifungal volatile compounds evolved from solarized soil amended with cabbage residues. Phytopathology 83, 899-905.
Granatstein, D., Mazzola, M., 2001. Alternatives to fumigation for control of apple replant problem in Washington State orchards. Bulletin-OILB/SROP 24, 265-271.

Gu, Y.H., Mazzola, M., 2003. Modification of pseudomonad community and control of apple replant problem induced in a wheat cultivar-specific manner. Applied Soil Ecology 24, 57-72.

Gur, A., Cohen, Y., Katan, J., Barkai, Z., 1991. Pre plant application of soil fumigants and solarization for treating replant diseases of peaches and apples. Scientia Horticulturae 45(3-4), 215-224.

Gur, A., Luzzati, J., Katan, J., Utkliede, R., Veghelyi, K., 1998. Alternatives for soil fumigation in combating apple replant problem. Acta Horticulturae 477, 107-113.

Harman, G.E., Taylor, A.G., Stasz, T.E., 1989. Combining strains of Trichoderma harzianum and solid matrix priming to improve biological seed treatments. Plant Diseases 73, 631.

Hoestra, H., 1994. Ecology and pathology of replant problems. Acta Horticulturae 363, 1-10

Hoyt, P.B., Neilson, G.H., 1985. Effect of soil pH and associated cations on growth of apple trees planted in old orchard soil. Plant and Soil 86, 395-401.

Hudska, G., Klimova, I., Kloutvorova, L., 1987. Influencing apple replant problem soil toxicity by $\mathrm{pH}$ adjustment. Vedecke Prace Ovocnarske 11, 91-98.

Isutsa, D.K., Merwin, I.A., 2000. Malus germplasm varies in resistance or tolerance to apple replant problem in a mixture of New York orchard soils. HortScience 35, 262-268.

Jackson, J.E., 1973. Effects of soil fumigation on the growth of apple and cherry rootstocks on land previously cropped with apple. Annals of Applied Biology 74, 99-104.

Jaffee, B.A., Abawi, G.S., Mai, W.F., 1982. Role of soil microflora and Pratylenchus penetrans in an apple replant problem. Phytopathology 72, 247-251.

Jensen, P., Buszard, D., 1988. The effect of chemical fumigants, nitrogen, plastic mulch and metalaxyl on the establishment of young apple trees in apple replant problem soil. Canadian Journal of Plant Science 68, 255-260.

Jonkers, H., Hoestra, H., 1978. Soil pH in fruit trees in relation to specific replant disorder of apple. Scientia Horticulturae 8(2), 113-118.

Kandula, D.R.W., Jones, E.E., Horner, I.J., Stewart, A., 2010. The effect of Trichoderma bio-inoculants on specific apple replant problem (SARD) symptoms in apple rootstocks in New Zealand. Australasian Plant Pathology 39(4), 312-318.

Kandula, D.R.W., Jones, E.E., Stewart, A., Horner, I.J., 2006. Colonisation of apple roots by arbuscular mycorrhizae in specific apple replant problem affected soil. New Zealand Plant Protection 59, 92-96.

Kelderer, M., Manici, L.M., Caputo, F., Thalheimer, M., 2012. 
Planting in the 'inter-row' to overcome replant disease in apple orchards: a study on the effectiveness of the practice based on microbial indicators. Plant and Soil 357, 381-393

Kowalik, M., 1999. Soil fungi and the replant disease in an apple orchard. Phytopathologia Polonica 17, 31-40.

Kumar, R., Pandey, J.C., Verma, B.L., 1998. Chemical control of replant disease of apple. Recent Horticulture 4, 64-68.

Laurent, A., St. Merwin, I.A., Thies, J.E., 2008. Long-term orchard groundcover management systems affect soil microbial communities and apple replant problem severity. Plant and Soil 304, 209-225.

Laurent, S., Merwin, A., Fazio, IA., Thies, G., Brown, J.E., 2010. Rootstock genotype succession influences apple replant problem and root-zone microbial community composition in an orchard soil. Plant and Soil 337(1/2), 259-272.

Lazarovits, G., 2001. Management of soil-borne plant pathogens with organic soil amendments: a disease control strategy salvaged from the past. Canadian Journal of Plant Pathology 23, 1-7.

Leinfelder, M.M., Merwin, I.A., 2006. Rootstock selection, pre plant soil treatments and tree planting positions as factors in managing apple replant problem. HortScience 41(2), 394-401.

Li, T.S.C., Utkhede, R.S., 1991. Effects of pH and nutrients on growth of apple seedlings grown in apple replant problem soils of British Columbia. Canadian Plant Disease Survey 71, 29-32.

Line, M., Heath, A., Brown, G., 2003. Apple replant problem - available fumigation treatments. Tree Fruit 9, 22-23.

Magarey, R.C., 1999. Reduced productivity in long term monoculture: where are we placed? Australasian Plant Pathology 28, 11-20.

Mai, W.F., Merwin, I.A., Abawi, G.S., 1994. Diagnosis, etiology, and management of replant problems in New York cherry and apple orchards. Acta Horiculturae 363, 33-41.

Manici, L.M., Caputo, F., 2010. Soil fungal communities as indicators for replanting new peach orchards in intensively cultivated area. European Journal of Agronomy 33, 188-196.

Manici, L.M., Ciavatta, C., Kelderer, M., Erschbaumer, G., 2003. Replant problems in South Tyrol: role of fungal pathogens and microbial population in conventional and organic apple orchards. Plant and Soil 256, 315-324.

Mazzola, M., 1998. Elucidation of the microbial complex having a causal role in the development of apple replant problem in Washington. Phytopathology 88, 930-938

Mazzola, M., 1999. Transformation of soil microbial community structure and Rhizoctonia-suppressive potential in response to apple roots. Phytopathology 89, 920-927.

Mazzola, M., 2003. Elucidation of the microbial complex having a casual role in the development of apple replant problem in Washington. Phytopathology 88 (9),
930-938.

Mazzola, M., Gu, Y.H., 2000. Impact of wheat cultivation on microbial communities from replant soils and apple growth in greenhouse trials. Phytopathology 90, 114-119.

Mazzola, M., Mullinix, K., 2005. Comparative field efficacy of management strategies containing Brassica napus seed meal or green manure for the management of apple replant problem. Plant Disease 89, 1207-1213.

Mazzola, M., Andrews, P.K., Reganold, J.P., Levesque, C.A., 2002. Frequency, virulence, and metalaxyl sensitivity of Pythium spp. isolated from apple roots under conventional and organic production systems. Plant Disease 86, 669-675.

Mazzola, M., Brown, J., Izzo, A.D., Cohen, M.F., 2007. Mechanism of action and efficacy of seed meal-induced pathogen suppression differ in a Brassicaceae species and time-dependent manner. Phytopathology 97, 454-60.

Mazzola, M., Brown, J., Izzo, A., Ghanem, R.A., Cohen, M.F., 2006. Progress towards development of biologicallybased strategies for the management of apple replant problem. Phytopathologia Polonica 39, 11-18.

Mazzola, M., Brown, J., Zhao, X., Izzo, A.D., Fazio, G., 2009. Interaction of brassicaceous seed meal and apple rootstock on recovery of Pythium spp. and Pratylenchus penetrans from roots grown in replant soils. Plant Disease 93, 51-57.

Mazzola, M., Granatstein, D.M., Elfving, D.C., Mullinix, M.K., 2001. Suppression of specific apple root pathogens by Brassica napus seed meal amendment regardless of glucosinolate content. Phytopathology 91, 673-679.

Merwin, F.A., Stiles, W.C., 1989. Root lesion nematodes, potassium deficiency and prior cover crops as factor in apple replant problem. Journal of the American Society for Horticultural Science 114, 724-728.

Molnar, P., Veghelyi, K., Balogh, I., 2003. Grapevine and apple replant problem in Hungary. International Journal of Horticultural Science 9(1), 29-33.

Moyls, A.L., Hocking, R.P., Neilsen, G.H., Hogue, E.J., 1994. Apple tree growth response in greenhouse pot tests using heat-treated replant soil versus orchard replanted trees with in situ heated soil. Acta Horticulturae 363, 57-64.

Noble, R., Coventry, E., 2005. Suppression of soil-borne plant diseases with composts: a review. Biocontrol Science and Technology 15, 3-20.

Oehl, V.H., 1980. The long-term effects of pre-planting soil fumigation on the growth and cropping of cvs. Laxton's Fortune and Cox's Orange Pippin on M.2 rootstock, planted on land affected with a replant disease of apple. Journal of Horticultural Science 55(3), 259-266.

O'Kennedy, N.D., Kavanagh, T., 1980. Effects of the specific apple replant problem on growth and cropping of three 
apple scion cultivars on Malling 9 rootstock. Irish Journal of Agricultural Research 19(2/3), 127-131.

Otto, G., 1972. Studies on the cause of specific replant disease of fruit trees. Experiments on the transfer of specific replant disease by the roots. Zentralblatt fur Bakteriologie, Parasitenkunde, Infektionskrankheiten und Hygiene 127, 279-289.

Otto, G., Winkler, H., 1977. Investigations on the cause of replant disease in fruit trees. VI. Detection of actinomycetes in feeder roots of apple seedlings in soils with different degrees of replant disease. Zentralblatt fur Bakteriologie, Parasitenkunde, Infektionskrankheiten und Hygiene 132(5/6), 593-606.

Otto, G., Winkler, H., 1993. Colonization of rootlets of apple seedlings from replant soils by actinomycetes and endotrophic mycorrhiza. Acta Horticulturae 324, 53-59.

Otto, G., Winkler, H., 1998. Influence of root pathogenic actinomycetes on the trimming of the rootlets of some species of Rosaceae with root hairs. Acta Horticulturae 477, 49-54.

Otto, G., Winkler, H., Szabo, K., 1994. Influence of growth regulators on the infection of rootlets of apple seedlings in SARD soils by actinomycetes. Acta Horticulturae 363, 101-108.

Potter, D., 1999. Specific apple replant problem - the search for solutions. The Orchardist, 75.

Rabie, L., Denman, S., Cook, N.C., 2001. Apple replant problem: alternatives to methyl bromide. Deciduous Fruit Grower 51, 29-32.

Raj, H., Sharma, S.D., 2009. Integration of soil solarization and chemical sterilization with beneficial microorganisms for the control of white root rot and growth of nursery apple. Scientia Horticulturae 119, 126-131.

Ristaino, J.B., Thomas, W., 1997. Agriculture, methyl bromide and the ozone hole can we fill the gaps? Plant Disease 81, 964-977.

Robinson, T.G., Fazio, H.A., Hoying, S., 2004. Performance of the new Geneva apple rootstocks in trials in the US, NZ and Europe. Compact Fruit Tree 37(3), 91-94.

Ross, R.G., Crowe, A.D., 1973. Replant disease in apple orchard soil. Canadian Plant Disease Survey 53, 144-146.

Ross, R.G., Delbridge, R.W., Kimpinski, J., McRae, K.B., 1983. Control of apple replant problem in Nova Scotia by soil fumigation with vorlex and chloropicrin. Canadian Journal of Plant Pathology 5(3), 177-180.

Rumberger, A., Merwin, I.A., Thies, J.E., 2007. Microbial community development in the rhizosphere of apple trees at a replant site. Soil Biology and Biochemistry 39, 1645-1654.

Rumberger, A., Yao, S., Merwin, I.A., Nelson, E.B., Thies, J.E., 2004. Rootstock genotype and orchard replant position rather than soil fumigation or compost amendment determine tree growth and rhizosphere bacterial community composition in an apple replant soil. Plant and Soil 26, 247-260.

Ryan, C.L.J., 1975. Specific replant disease in Hawkey's Bay Part IV: Control methods including fumigation technique. Orchardist of New Zealand 48, 194-195.

Schoor, L.V., Denman, S., Cook, N.C., 2009. Characterization of apple replant problem under South African conditions and potential biological management strategies. Scientia Horticulturae 119, 153-162.

Sewell, G.W.F., 1979. Reappraisal of the nature of the "specific replant disease" of apple. Review of Plant Pathology 58, 209-211.

Sewell, G.W.F., 1981. Effects of Pythium species on the growth of apple and their possible causal role in apple replant problem. Annals of Applied Biology 97, 31-42.

Sewell, G.W.F., White, G.C., 1979. The effect of formalin and other soil treatments on the replant disease of apple. Journal of Horticultural Science 54(4), 333-335.

Sewell, G.W.F., Sivakadadcham, B., Pullinger, J., 1982. Replant disease and poor growth of apple. East Malling Research Station Report for 1981, 80.

Singh, N., Sharma, D.P., 2017. Soil treatments and rootstocks against apple replant problem. International Journal of Chemical Studies 5(6), 2164-2170.

Singh, N., Sharma, D.P., Kumar, V., 2017. Managing apple replant problem: the effect of rootstocks and soil treatments on tree performance and biological activities. Journal of Pharmacognosy and Phytochemistry 6(6), 2554-2559.

Singh, N., Sharma, D.P., Kumar, V., Hota, D., 2018. Impact of different rootstocks and soil agro-techniques on rhizospheric biological activities and growth traits under apple replant sick soil. Multilogic in Science 88-92.

Slykhuis, J.T., Li, T.S.C., 1985. Response of apple seedlings to biocides and phosphate fertilizers in orchard soils in British Columbia. Canadian Journal of Plant Pathology 7, 294-301.

Soni, M., Thakur, M., Modgil, M., 2011. In vitro multiplication of Merton I. 793-An apple rootstock suitable for replantation. Indian Journal of Biotechnology 10, 362-368.

Szabo, K., Winkler, H., Petzold, H., Marwitz, R., 1998. Evidence for the pathogenity of actinomycetes in rootlets of apple seedlings from soil conducive to specific apple replant problem. Acta Horticulturae 477, 55-65.

Szczygiel, A. and Zepp, A.L., 1998. An occurrence and importance of apple replant problem in Polish orchards. Acta Horticulturae 77, 99-102.

Taube, B.H., Baltruschat, H., 1993. Effect of vesiculararbuscular mycorrhizal fungi on the growth of young apple trees in apple replant problem soil. Journal of Plant Diseases and Protection 100, 474-481.

Thompson, J.A., 1959. The occurrence of areas or poor growth in a fruit tree nursery. Report of East Malling Research Station 80-82. 
Townshend, J.L., Cline, R.A., Dirks. V.A., Marks, C.F., 1984. Assessment of turf grasses for the management of Pratylenchus penetrans and Pratylenchus projectus in orchards. Canadian Journal of Plant Science 64, 355-360.

Utkhede, R.S., Li, T.S.C., 1988. The role of fungi, bacteria and their interaction in apple replant problem complex in soils of British Columbia. Acta Horticulturae 233, 75-80.

Utkhede, R.S., Li, T.S.C., 1989. Chemical and biological treatments for control of replant disease in British Columbia. Canadian Journal of Plant Pathology 11, 143-147.

Utkhede, R.S., Smith, E.M., 1991a. Effect of nitrogen and phosphorus on the growth of microorganisms associated with apple replant problem and on apple seedlings grown in soil infested with these microorganisms. Journal of Phytopathology 132, 1-11.

Utkhede, R.S., Smith, E.M., 1991b. Phytophthora and Pythium species associated with root rot of young apple trees and their control. Soil Biology and Biochemistry 23, 1059-1063.

Utkhede, R.S., Smith, E.M., 1992. Promotion of apple tree growth and fruit production by the EBW-4 strain of Bacillus subtilis in apple replant problem soil. Canadian Journal of Microbiology 38(12), 1270-1273.

Utkhede, R.S., Smith, E.M., 1993. Evaluation of monoammonium phosphate and bacterial strains to increase tree growth and fruit yield in apple replant problem soil. Plant and Soil 157(1), 115-120.

Utkhede, R.S., Smith, E.M., 1994. Development of biological control of apple replant problem. Acta Horticulturae 363, 129-134.

Utkhede, R.S., Smith, E.M., 2000. Impact of chemical, biological and cultural treatments on the growth and yield of apple in replant-disease soil. Australasian Plant Pathology 29(2), 129-136.

Utkhede, R.S., Smith, E.M., Palmer, R., 1992. Effect of root rot fungi and root-lesion nematodes on the growth of young apple trees grown in apple replant problem soil. Journal of Plant Diseases and Protection 99, 414-419.

Vrain, T.C., Yorston, J.M., 1987. Plant parasitic nematodes in orchards in the Okanagan of British Columbia. Canadian Plant Disease 71, 85-87.

Waechter, K.B., 1988. On the possible implication of ethylene releasing bacteria in the specific apple replant problem-
(SARD)-complex. Mededelingen van de Faculteit Landbouwwetenschappen, Rijksuniversiteit Gent 53(2), 535-541.

Wang, Y.Z., Yin, C.M., Chen, Q., Shen, X., Jiang, Z.T. and Mao, Z.Q., 2011. Study on the difference of adaptability to replant soil in five apple rootstock seedlings. Acta Horticulturae Sinica 38(10), 1955-1962.

Westcott, I.S.W., Beer, S.V., Israel, H.W., 1987. Interaction between actinomycete-like organisms and young apple roots grown in soil conducive to apple replant problem. Phytopathology 77, 1071-1077.

Westcott, W.I., Beer, S.V., Stiles, W.C., 1986. Infection of apple roots by actinomycetes associated with soils conducive to apple replant problem. Plant Disease 70(12), 11251128.

Willett, M., Smith, T.J., Peterson, A.B., Hinman, H., 1994. Growing profitable apple orchards in replant sites: an interdisciplinary approach in Washington State. HortTechnology 4, 175-180.

Williams, R.F.V., 1984. Apple: control of apple replant problem. Annual Review, Brogdale Experimental Horticulture Station, 20.

Wilson, S., Andrews, P., Nair, T.S., 2004. Non fumigant management of apple replant problem. Scientia Horticulturae 102, 221-231.

Winkler, H., Otto, G., 1972. Studies on the cause of specific replant disease of fruit trees. IV. The effect of different steaming temperatures on free-living nematodes in sick soil. Zentralbl Bakteriol Parasitenkd Infektionskr Hyg 127(7/8), 783-788.

Winkler, H., Szabo, K., 1995. Filamentous bacteria cause specific replant disease. Gartenbaumagazin 4(8), 34-35.

Wojcik, P., Klamkowski, K., 2008. Response of 'Jonagold' apple trees in the first three years after planting to monoammonium phosphate fertilizer under replant problem condition. Journal of Plant Nutrition 28(8), 1397-1411.

Yao, S., Merwin, I.A., Abawi, G.S., Thies, J.E., 2006. Soil fumigation and compost amendment alter soil microbial community composition but do not improve tree growth or yield in an apple replant site. Soil Biology and Biochemistry 38, 587-599. 